\title{
Contributions of phytoplankton and bacteria to the optical backscattering coefficient over the Mid-Atlantic Ridge
}

\author{
Victor Martinez-Vicente*, Gavin H. Tilstone, Shubha Sathyendranath, \\ Peter I. Miller, Steve B. Groom
}

Plymouth Marine Laboratory, Prospect Place, The Hoe, Plymouth PL1 3DH, UK

\begin{abstract}
Understanding the sources of the optical backscattering coefficient from particles $\left(b_{\mathrm{bp}}\right)$ aids interpretation of ocean colour measured from satellites. The hypothesis tested is that phytoplankton make a significant contribution to the $b_{\mathrm{bp}}$ in the open ocean. Using phytoplankton pigment, flow cytometry and microscopy data, measured concurrently with in situ $b_{\mathrm{bp}}$ in the central North Atlantic Ocean, we separated the phytoplankton signal from that of bacteria. Three distinct pelagic communities were detected, all associated with the sub-polar front. A significant percentage of variance in the $b_{\mathrm{bp}}$ signal $\left(\mathrm{r}^{2}=0.68\right)$ was explained by phytoplankton between 2 and $20 \mu \mathrm{m}$ in diameter (nanoeukaryotes). To further test the hypothesis, $b_{\mathrm{bp}}$ was calculated using literature values of the backscattering properties and cell size of phytoplankton and flow-cytometric cell counts. In agreement with previous modelling studies, bacteria, due to their great abundance, dominate the biological $b_{\mathrm{bp}}$ signal. However, the variations in $b_{\mathrm{bp}}$ were related to changes in phytoplankton abundance (particularly of nanoeukaryotes), and the use of high backscattering efficiency factors per cell for nanoeukaryotes yielded computed values close to the observed $b_{\mathrm{bp}}$. We found no evidence that the detrital component played a significant role in $b_{\mathrm{bp}}$ at this site. However, given the limited methods available to test this result, such lack of evidence is inconclusive. To be able to explain the remaining proportion of the variation in $b_{\mathrm{bp}}$ a significant methodological advance is required for the better quantification and characterisation of the organogenic detritus.
\end{abstract}

KEY WORDS: Optical backscattering $\cdot$ Mid-Atlantic Ridge $\cdot$ Optics $\cdot$ Nanoeukaryotes $\cdot$ Bacteria

\section{INTRODUCTION}

Accounting for the biological contribution to the marine optical particle backscattering coefficient $\left(b_{\mathrm{bp}}\right)$ in the visible range is an area of active research (Stramski et al. 2004). An important application of this research is the construction of remote-sensing algorithms capable of detecting different types of phytoplankton from inherent optical properties such as $b_{\mathrm{bp}}$ (Boss et al. 2004). According to some scattering models, bacteria are the greatest contributors to $b_{\mathrm{bp}}$ of all living organisms (Stramski \& Kiefer 1991, Stramski et al. 2001). Relationships between chlorophyll a (chl a) concentration and $b_{\mathrm{bp}}$ have been reported (Ulloa et al. 1994, Morel \& Maritorena 2001, Huot et al. 2008); however, it has been hypothesized that the small nonliving particles that co-vary with phytoplankton (i.e. detritus), could be responsible for the 'missing' backscattering component (Stramski et al. 2001, 2004). Another possibility is that the role of phytoplankton is underestimated in models based on homogeneous spheres (Vaillancourt et al. 2004, Bernard et al. 2009). The aim of this study was to explore the variation of $b_{\mathrm{bp}}$ in relation to living organisms in the open ocean, 
using a dataset in which the range in chl a is small, but the change of the pico- and nanoplankton community is high, such that their individual contribution to $b_{\mathrm{bp}}$ can be discerned.

To aid in the understanding of bulk optical properties of the ocean, flow cytometry has been used for studies of the absorption coefficient (Perry \& Porter 1989). Other studies have combined flow cytometric counts of the marine pico- and nanoplankton communities with attenuation and scattering (Durand \& Olson 1996, Chung et al. 1998, Claustre et al. 1999, Green et al. 2003a, Oubelkheir et al. 2005, Grob et al. 2007, Montes-Hugo et al. 2009).

During July and August 2007, a cruise over the Mid-Atlantic Ridge (MAR), between 48 and $54^{\circ} \mathrm{N}$, 25 and $40^{\circ} \mathrm{W}$ (ECOMAR cruise) provided an opportunity to sample an oceanic region where the biooptical parameters had not been previously studied. The MAR at these latitudes is interrupted by the Charlie Gibbs fracture, and the water mass circulation of the area is characterised by intense mesoscale activity (Read et al. 2010). This has ecological significance for higher trophic levels (Letessier et al. 2009). Some studies on water masses south of the MAR (e.g. north Sargasso Sea), have reported that non-photosynthetic bacteria in those waters contain the same amount of carbon as the prochlorophytes and photosynthetic eukaryotes combined (Li et al. 1992, Li \& Harrison 2001, Li 2002).

The work presented here consists of 2 parts. The first is a description of the abundance and distribution of biological and bio-optical properties of the area in their environmental context. Phytoplankton and bacterial distributions were studied using pigments, flow cytometry and microscopy. The biological observations characterised 3 different ecosystems that had contrasting $b_{\mathrm{bp}}$. Measurements of the main variable of interest in this study (viz. $b_{\mathrm{bp}}$ ) are accompanied by concurrent data on particulate absorption, whose detrital fraction is used as a proxy for detritus abundance. The second part of the paper is a biooptical analysis of the relationship between $b_{\mathrm{bp}}$ and the abundance of phytoplankton, bacteria and detrital matter. Empirical relationships between particle abundance and $b_{\mathrm{bp}}$ provide insight into the effect of the biotic size-structure on variations in $b_{\mathrm{bp}}$. A simplified budget for $b_{\mathrm{bp}}$, calculated using in situ abundances of each compartment, backscattering efficiency factors $\left(Q_{\mathrm{bbp}}\right)$ and nominal sizes of particles from the literature, is compared to measured $b_{\mathrm{bp}}$. This exercise gives us insight into the biological causes of the variations in $b_{\mathrm{bp}}$, beyond the relationship with chl a.

\section{MATERIALS AND METHODS}

Between 13 July and 18 August 2007, the area of the MAR around the Charlie Gibbs Fracture Zone (CGFZ) was surveyed from the RRS 'James Cook'. Optical casts $(\mathrm{N}=23)$ were carried out in parallel with discrete water samples taken from a CTD rosette $( \pm 30$ min difference between water sampling and optical sampling). Mixed-layer depth was defined using the sigma-t profiles as the depth where there was a difference of $0.125 \mathrm{~kg} \mathrm{~m}^{-3}$ from the surface density (Levitus 1982). The water samples were collected for the characterisation of particulate matter present, and were related to the $b_{\mathrm{bp}}$ from in-water optical measurements.

\section{Phytoplankton pigments, microscopic counts and flow-cytometric measurements}

Water was collected at from 3 to 6 depths using Niskin bottles on the CTD rosette. Water collected was filtered (1 to 41 per sample) for HPLC pigment analysis and particulate absorption measurements. A portion was preserved for flow cytometric studies and microscopy counts. Samples for pigment and particulate absorption measurements were filtered onto $25 \mathrm{~mm}$ GF/F filters, flash-frozen and kept at $-80^{\circ} \mathrm{C}$ until further analysis, which was carried out within 3 mo of collection. Analysis of phytoplankton pigments was carried out following the method of Barlow et al. (1997), adapted for the Agilent 110 series HPLC. $\mathrm{A}_{8}$ column was used in combination with a methanol-based binary solvent system following a linear gradient. The method provides good resolution with a run time of $32 \mathrm{~min}$, excluding a postrun time of $7 \mathrm{~min}$ prior to the next injection. An internal standard, apo-8'-carotenal, was used in the extraction solvent to help improve the accuracy of the analysis. The separation of divinyl chl $a$ and of the carotenoids zeaxanthin and lutein, is achieved, but $\alpha$ and $\beta$-carotenes and $\operatorname{chl} c_{1}$ and $c_{2}$ are not separated by this method.

Analytical flow cytometric (AFC) samples were fixed with pre-filtered $(0.1 \mu \mathrm{m})$ gluteraldehyde to a final concentration of $1 \%$. Samples with gluteraldehyde were then left for at least $1 \mathrm{~h}$ at $4^{\circ} \mathrm{C}$ in the dark and then flash-frozen in liquid $\mathrm{N}$ and stored at $-80^{\circ} \mathrm{C}$ until analysis. Analysis was carried out using Becton Dickinson FACSort and Coulter FACScan flow cytometers, and the flow rate was monitored regularly using fluorescent polystyrene beads (Tarran et al. 2001, Tarran et al. 2006). The following planktonic 
groups were quantified in the samples: heterotrophic bacteria, Prochlorococcus spp., Synechococcus spp., picoeukaryotic phytoplankton, nanophytoplankton, cryptophytes and coccolithophores. Heterotrophic bacteria were analysed using a DNA dye (SYBR Green 1) to produce a fluorescent signal (Zubkov et al. 2000). Bacteria were enumerated separately as high-nucleic-acid-containing and low-nucleic-acidcontaining cells, and the bacteria counts presented are the sum of these 2 types. Coccolithophorid abundances were insignificant throughout the cruise, and are not reported here. Flow-cytometric counts were triggered by fluorescence rather than by side-scattering, such that only fluorescent particles (photosynthetic or stained bacteria) were counted, and not the whole particle population. Seawater samples of $\sim 50 \mathrm{ml}$ were collected for microscopic floristic studies and preserved in gluteraldehyde to a final concentration of $1 \%$ and kept in the dark at $4^{\circ} \mathrm{C}$ until analysis. To calculate abundances of dinoflagellates and diatoms with a diameter greater than $20 \mu \mathrm{m}, 9$ samples from $30 \mathrm{~m}$ depth, collected in different locations, were analysed. These samples were recovered after the microscopy examination, so that a full floristic study can be made in the future.

\section{Detrital particulate absorption}

Following the method of Tassan \& Ferrari (1995), particulate absorption coefficients of total particulate $\left(a_{\mathrm{p}}\right)$ and non-algal particles $\left(a_{\mathrm{NAP}}\right)$ retained on $25 \mathrm{~mm}$ GF/F filters were measured. This measurement was made before and after pigment extraction using $\mathrm{NaClO} 1 \%$ active chloride from 350 to $750 \mathrm{~nm}$ at a $1 \mathrm{~nm}$ bandwidth on a dual-beam Perkin-Elmer Lambda-900 spectrophotometer retro-fitted with a spectralon-coated integrating sphere. The spectrophotometer is calibrated annually using Holmium Oxide filters. Correction for pathlength amplification on the filters followed Tassan \& Ferrari (1995) on both the particulate and detrital fractions.

\section{Optical backscattering coefficient}

For optical measurements of the total backscattering coefficient, a Wetlabs BB3 was used. Upcast data on $\beta(117)$, the volume scattering coefficient at $117^{\circ}$, were selected; data reduction included median filtering and binning to $0.5 \mathrm{~m}$ intervals. Computation of the particle backscattering coefficient $\left(b_{\mathrm{bp}}\right)$ was achieved by subtracting the pure seawater scattering $\left(\beta_{\mathrm{sw}}(117)\right)$ from $\beta(117)$ to obtain $\beta_{\mathrm{p}}(117)$, the particle volume scattering coefficient at $117^{\circ} . b_{\mathrm{bp}}$ is estimated using a factor $\chi_{\mathrm{p}}(117)$ following Twardowski et al. (2007):

$$
b_{\mathrm{bp}}=2 \pi \chi_{\mathrm{p}}(117)\left[\beta(117)-\beta_{\mathrm{sw}}(117)\right]
$$

where $\chi_{\mathrm{p}}(117)$ was assumed to be 0.90 (Sullivan et al. 2005). Because of the short pathlength of the instrument, the correction for absorption and attenuation was considered negligible and therefore not applied to the data. Calibration of the instrument was performed by the manufacturer prior to the cruise. Following Twardowski et al. (2007), no dark-offset measurements were performed during the cruise and it was assumed that there was no significant instrument drift. We chose for this study a wavelength centred around $532 \mathrm{~nm}$, to avoid any possible interference from absorption or fluorescence.

\section{Conceptual model}

The objective of this study was to assess the contributions of living organisms to the magnitude of $b_{\mathrm{bp}}$. Although bubbles are known to contribute significantly to $b_{\mathrm{bp}}$ (Zhang et al. 1998), their role is not studied here. The contributions of living particles to $b_{\mathrm{bp}}$ can be represented in the following simplified budget:

$$
b_{\mathrm{bpl}}=\sum_{i=1}^{\mathrm{n}} b_{\mathrm{bp} i}=\sum_{i=1}^{8} \mathrm{C}_{\mathrm{p} i} \sigma_{\mathrm{bbp} i}
$$

where $C_{\mathrm{p} i}$ is the concentration (in cells $\mathrm{m}^{-3}$ ) for each type of living particle $i$, viz. bacteria, Prochlorococcus spp., Synechococcus spp., picoeukaryotes, nanoeukaryotes, coccolithophorids, dinoflagellates and diatoms. The backscattering cross-section (in $\mathrm{m}^{2}$ ) of a single particle of the $i$ th component $\left(\sigma_{\mathrm{bbp} i}\right)$ is the product of the mean geometric cross-section of the particle $\left(S_{i}\right.$ in $\mathrm{m}^{2}$ cell $\left.^{-1}\right)$ and the efficiency factor for backscattering ( $Q_{\mathrm{bbp} i}$, dimensionless) of the particle $i$. Then, $b_{\mathrm{bp} i}$ is computed as:

$$
b_{\mathrm{bp} i}=C_{\mathrm{p} i} \times\left(S_{i} \times Q_{\mathrm{bbp} i}\right)
$$

\section{RESULTS}

\section{Environment, plankton distribution and bio-optical properties}

During the ECOMAR cruise we found a high surface temperature gradient (Fig. 1a). We used this front to delimit 3 areas. South of the front, the surface waters were warmer $\left(\sim 15.5^{\circ} \mathrm{C}\right)$ and more saline 

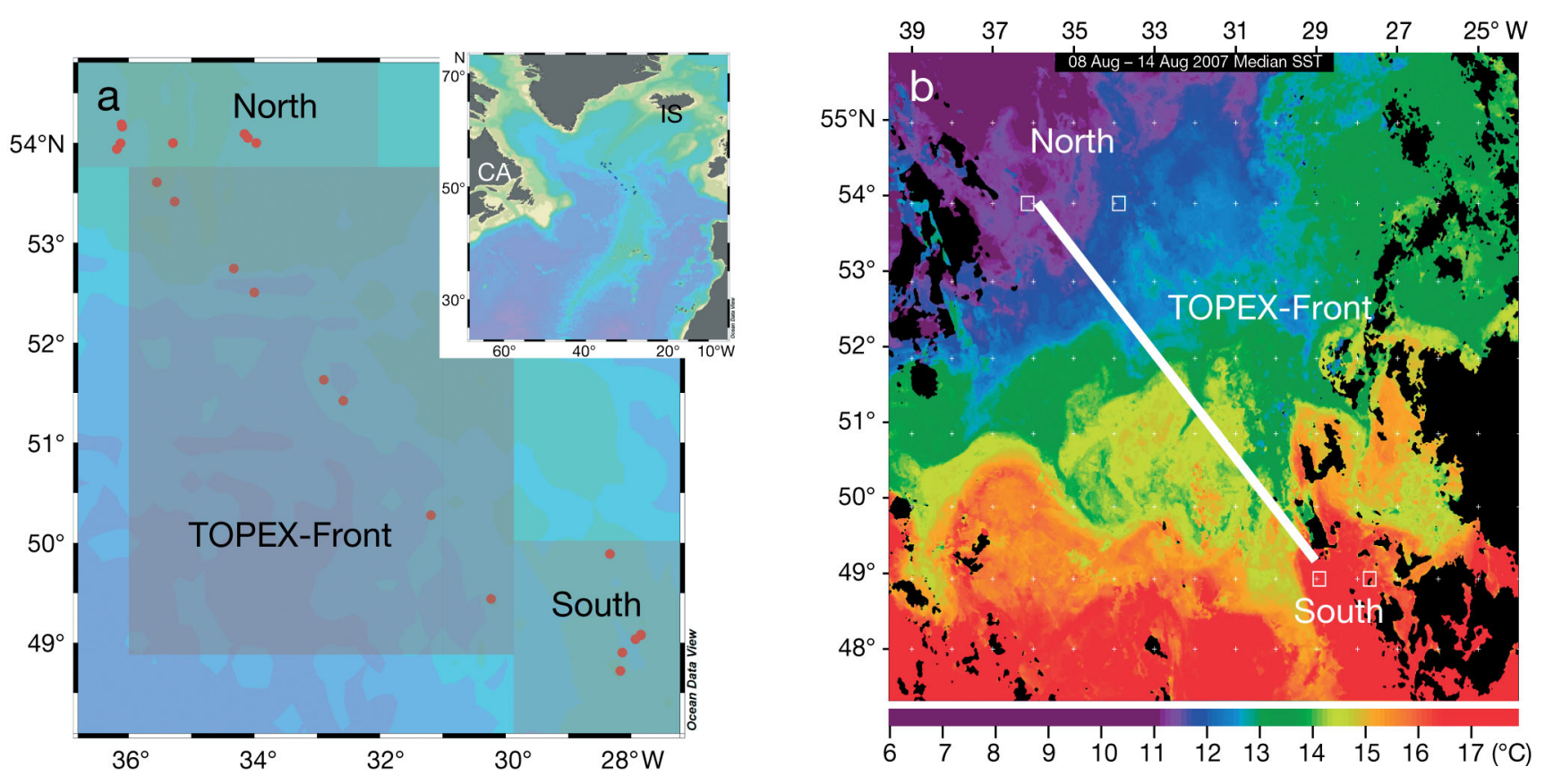

Fig. 1. (a) Location of sampling stations (red dots) over Mid-Atlantic Ridge (North Atlantic). The 3 large shaded rectangles indicate the 3 areas in which stations were grouped. Some casts occurred at same positions as other casts. Inset: $\mathrm{CA}=\mathrm{Canada}$; IS = Iceland. (b) Surface temperature gradient in sampling areas as described by weekly composite image of sea surface temperature from spaceborne Advanced Very High Resolution Radiometer during the ECOMAR cruise. Scale goes from $6^{\circ} \mathrm{C}$ (purple) to $18^{\circ} \mathrm{C}$ (red). Squares: positions of main biological stations around which bio-optical sampling took place; white line: position of TOPEX transect (frontal area), which crosses sub-polar front

( $235.6 \mathrm{psu})$. Across the sub-polar front, the average surface temperature was $\sim 13.4^{\circ} \mathrm{C}$ and salinity $35.0 \mathrm{psu}$, with cold water found at shallow depths $\left(7^{\circ} \mathrm{C}\right.$ at $\left.40 \mathrm{~m}\right)$. The average surface temperature north of the front was $10.5^{\circ} \mathrm{C}$. The mean mixed-layer depth in the south was $43 \pm 7 \mathrm{~m}$ ( 6 casts). Over the front, the mixed layer became shallower $(23 \pm 10 \mathrm{~m}, 7$ casts $)$. The front area was sampled following the TOPEXPoseidon track and, for consistency with previous studies (Read et al. 2010, Fig. 1b), will hereinafter be referred to as the 'TOPEX transect'. To the north, the mixed layer was deeper $(41 \pm 8 \mathrm{~m}, 10$ casts). The differences in terms of $T, S$ and mixed layer depth define 3 environments where we expected differences in the structure of the phytoplankton community and the bio-optical properties. Therefore our data are grouped according to 3 areas: the South, the TOPEX transect (front) and the North.

Pigments and counts of phytoplankton and bacteria

Phytoplankton pigment analysis showed that nearsurface chl $a$ was $<1 \mathrm{mg} \mathrm{m}^{-3}$ for most of the cruise, suggesting mesotrophic conditions (Fig. 2). Chl $a$ in the North area (Fig. 2a) was on average $<0.6 \mathrm{mg} \mathrm{m}^{-3}$ in the top $30 \mathrm{~m}(z<30 \mathrm{~m})$. Along the TOPEX transect (Fig. 2c), the chl a maximum was at $30 \mathrm{~m}$, and above the pycnocline it increased, with a highest single value of $1.3 \mathrm{mg} \mathrm{m}^{-3}$. In the South area, chl a values measured $<0.4 \mathrm{mg} \mathrm{m}^{-3}$ throughout the water column (Fig. 2e), with maxima at around $50 \mathrm{~m}$. Overall, the 3 areas had significantly different chl a levels: the South area had the lowest levels, and the TOPEX transect, across the sub-polar front, had the highest (ANOVA, $\mathrm{N}=79, F=14.3, \mathrm{p}<0.0001$ ).

Marker HPLC pigments were used to describe the composition and distribution of the phytoplankton community. Significant concentrations of divinyl $\mathrm{chl} a$ at stations in the South area indicated the presence of prochlorophytes (data not shown). This pigment was absent in the TOPEX and North areas. Fucoxanthin, a marker for diatoms (and some flagellates), and peridinin, a marker for dinoflagellates, were both present along the TOPEX transect and in the North area (Fig. 2). The fucoxanthin maximum $\left(0.267 \mathrm{mg} \mathrm{m}^{-3}\right)$ matched the position of the deep chlorophyll maximum at the TOPEX transect, but the concentration of fucoxanthin was very low in the South area. Fucoxanthin concentration varied considerably over the 3 areas, increasing from the South area (lowest) to the TOPEX transect and decreasing 

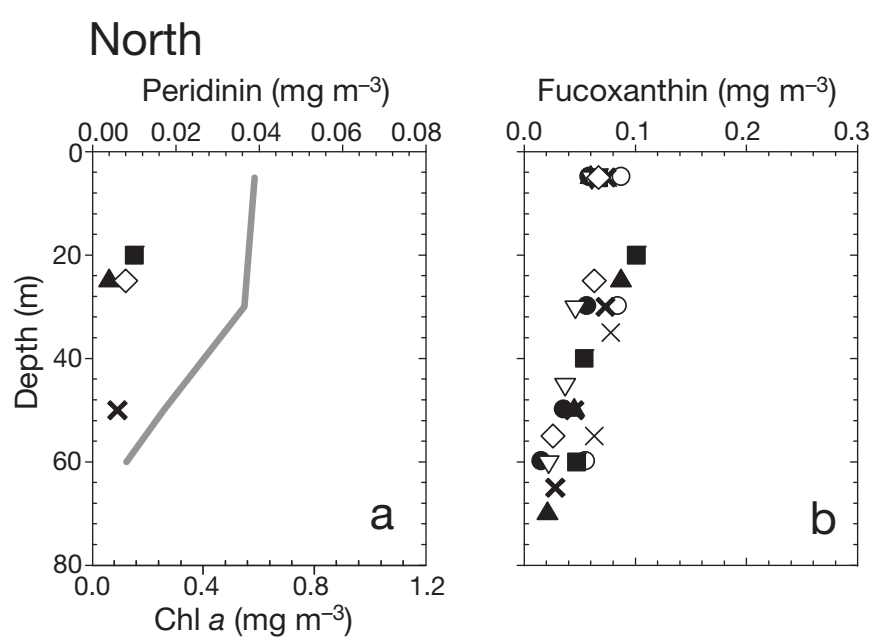

\section{TOPEX}
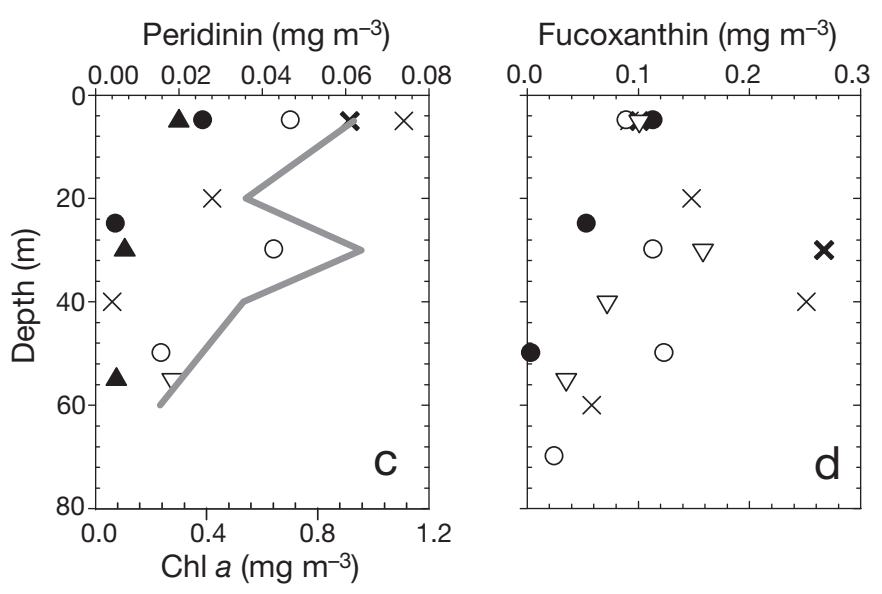

\section{South}

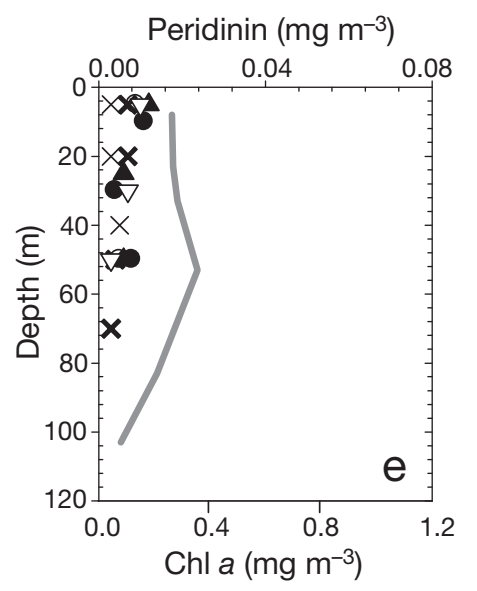

Fucoxanthin $\left(\mathrm{mg} \mathrm{m}^{-3}\right)$

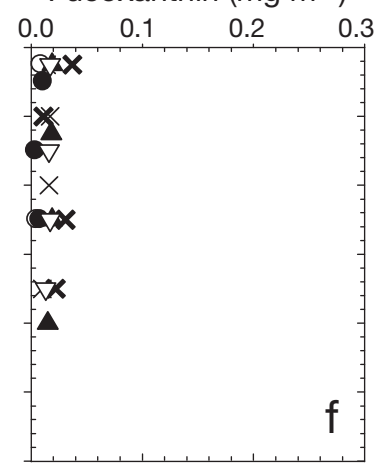

Fig. 2. Depth profiles of average chl a (grey line), peridinin and fucoxanthin concentrations for CTD casts in North, TOPEX and South areas. The relatively small number of data points in (a) is due to concentrations below limit of detection. Symbols represent different casts from TOPEX to the North area (ANOVA with $\mathrm{N}=78$, $F=30.3, \mathrm{p}<0.0001$ ) (Fig. 2c,d). Peridinin was generally low and found only in concentrations $>0.03 \mathrm{mg}$ $\mathrm{m}^{-3}$ in some profiles of the TOPEX transect (Fig. 2c) up to a maximum of $0.074 \mathrm{mg} \mathrm{m}^{-3}$, but its maxima generally did not match the chl a maxima. Peridinin concentration was highest along the TOPEX transect (ANOVA with $\mathrm{N}=38, F=8.7, \mathrm{p}<0.001$ ) and relatively low in the other 2 areas.

Average microscope and flow cytometry counts near the surface $(z<40 \mathrm{~m})$ are summarized in Table 1. Microscope counts confirmed the patterns seen in the pigment data: the greatest abundance of dinoflagellates and diatoms was found along the TOPEX transect, intermediate abundances were found in the North area and the lowest in the South. Flow cytometry indicated that bacterial abundance was not significantly different from one area to another. Prochlorococcus spp. were found only in the South and Synechococcus spp. abundance was highest at these stations (up to twice the abundance of the North or TOPEX; ANOVA, with $\mathrm{N}=44, F=46.7$, $\mathrm{p}<0.001$ ). Picoeukaryote abundances were not significantly different from the abundances in the TOPEX area, but were significantly lower than in the North (ANOVA, with $\mathrm{N}=44, F=3.9, \mathrm{p}<0.05$ ). Larger phytoplankton (cryptophytes and nanoeukaryotes) abundance was lowest in the South area. Nanoeukaryote abundance was highest in the North, whereas cryptophyte abundance was highest along the TOPEX transect.

For the whole dataset (all stations, $z<100 \mathrm{~m}$ ), the abundance of pico- and nanoplankton correlated positively with chl a concentration. Only Synechococcus spp. and Prochlorococcus spp. were uncorrelated with $\mathrm{chl} a$. Almost half the variation in chl $a$ $\left(\mathrm{r}^{2}=0.4, \mathrm{~N}=72, F=24, \mathrm{p}<0.001\right)$ could be explained by nanoplankton and cryptophyte abundances.

The pattern emerging from pigment analysis, microscopy counts and flow cytometry demonstrates the existence in our study area of 3 different ecosystems related to a prominent physical structure (i.e. the front). The South area had the lowest chl a concentrations and the smallest phytoplankton; the TOPEX transect, across the sub-polar front, had the highest chl a concentrations, with the largest cells; and the North area had intermediate-sized phytoplankton. Across these areas, although the range of chl a levels was relatively small, a high diversity of phytoplankton assemblages was recorded, with stable numbers of heterotrophic bacteria. Other sources of particulate matter were investigated using biooptical measurements. 
Table 1. Mean \pm SD abundances of bacteria, pico-, nano- and microphytoplankton (cell $\mathrm{l}^{-1}$ ) in the Mid-Atlantic Ridge area. $\mathrm{N}$ in parentheses. Dinoflagellates and diatoms $>20 \mu \mathrm{m}$ only

\begin{tabular}{|c|c|c|c|c|c|c|c|c|}
\hline & Bacteria & $\begin{array}{c}\text { Synechoccocus } \\
\text { spp. }\end{array}$ & $\begin{array}{l}\text { Prochloro- } \\
\text { coccus spp. }\end{array}$ & $\begin{array}{c}\text { Pico- } \\
\text { eukaryotes }\end{array}$ & $\begin{array}{c}\text { Nano- } \\
\text { eukaryotes }\end{array}$ & $\begin{array}{l}\text { Crypto- } \\
\text { phytes }\end{array}$ & $\begin{array}{l}\text { Dino- } \\
\text { flagellates }\end{array}$ & Diatoms \\
\hline North & $\begin{array}{c}1.3 \pm 0.5 \times 10^{6} \\
(16)\end{array}$ & $\begin{array}{c}1.7 \pm 0.5 \times 10^{4} \\
(19)\end{array}$ & Not detected & $\begin{array}{c}1.0 \pm 0.6 \times 10^{4} \\
(19)\end{array}$ & $\begin{array}{c}2.4 \pm 0.7 \times 10^{3} \\
(19)\end{array}$ & $\begin{array}{c}22 \pm 21 \\
(19)\end{array}$ & $6.3 \pm 2.1 \times 10^{3}$ & $\begin{array}{c}1.7 \pm 0.8 \times 10^{3} \\
(3)\end{array}$ \\
\hline TOPEX & $\begin{array}{c}1.1 \pm 0.8 \times 10^{6} \\
(12)\end{array}$ & $\begin{array}{c}2.5 \pm 1.9 \times 10^{4} \\
(12)\end{array}$ & Not detected & $\begin{array}{c}0.6 \pm 0.5 \times 10^{4} \\
(12)\end{array}$ & $\begin{array}{c}1.5 \pm 1.3 \times 10^{3} \\
(12)\end{array}$ & $\begin{array}{c}40 \pm 33 \\
(12)\end{array}$ & $\begin{array}{c}7.7 \pm 3.8 \times 10^{3} \\
(3)\end{array}$ & $\begin{array}{c}3.5 \pm 2.4 \times 10^{3} \\
(3)\end{array}$ \\
\hline South & $\begin{array}{c}1.4 \pm 0.3 \times 10^{6} \\
(12)\end{array}$ & $\begin{array}{c}8.0 \pm 2.9 \times 10^{4} \\
(12)\end{array}$ & $\begin{array}{c}4.6 \pm 2.1 \times 10^{4} \\
(13)\end{array}$ & $\begin{array}{c}0.7 \pm 0.3 \times 10^{4} \\
(13)\end{array}$ & $\begin{array}{c}0.8 \pm 0.6 \times 10^{3} \\
(13)\end{array}$ & $\begin{array}{c}7.1 \pm 8.2 \\
(13)\end{array}$ & $\begin{array}{c}1.1 \pm 0.6 \times 10^{3} \\
(3)\end{array}$ & $\begin{array}{c}0.2 \pm 0.1 \times 10^{3} \\
(3)\end{array}$ \\
\hline
\end{tabular}

Detritus absorption

The concentration of detrital particles is inferred from measurements of absorption by non-algal particles at $440 \mathrm{~nm}, a_{\mathrm{NAP}}(440)$. The mean $a_{\mathrm{NAP}}(440)$ for all data was $0.0030 \mathrm{~m}^{-1}(z<100 \mathrm{~m}, \mathrm{~N}=84, \mathrm{SD}=0.0024)$. Between South and North, $a_{\mathrm{NAP}}(440)$ was not significantly different, and it was lower in both these areas than along the TOPEX transect area (ANOVA, with $\mathrm{N}=83, F=5.2, \mathrm{p}<0.01)$. The detrital fraction of the total particulate absorption $\left(a_{\mathrm{NAP}}: a_{\mathrm{p}}\right)$ can be considered as an indicator of the relative importance of detrital particles (Stramski et al. 2001). This fraction varied from 1.2 to $41 \%$, with a median of $10 \%$, and decreased with increasing chl a levels (Fig. 3). This would indicate that changes in detritus contribution to the particulate pool in this area are not independent of biological activity. $a_{\mathrm{NAP}}(440)$ is used as an estimate of the amount of detritus and minerals in the relationship with $b_{\mathrm{bp}}$, presented hereinafter.

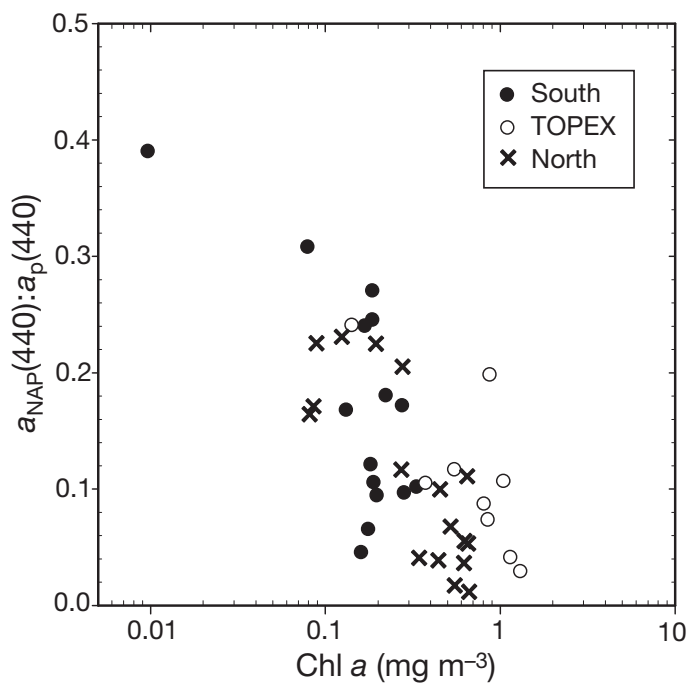

Fig. 3. Variation in contribution (at $440 \mathrm{~nm}$ ) of detrital particulate absorption to total particulate absorption ( $a_{\mathrm{NAP}}: a_{\mathrm{p}}$ ratio) with change in chl a. Symbols represent different casts
Particle backscattering coefficient

$b_{\mathrm{bp}}$ decreased with increasing depth for all areas (Fig. 4). For surface data $(z<40 \mathrm{~m})$, the overall mean was $0.0022 \pm 0.0010 \mathrm{~m}^{-1}(\mathrm{~N}=32$, coincident with water samples). The variation between areas indicates that $b_{\mathrm{bp}}(532)$ was significantly lower in the South than along the TOPEX transect or in the North (ANOVA, $\mathrm{N}=32, F=20.9, \mathrm{p}<0.0001$ ). The intra-area variability in $b_{\mathrm{bp}}(532)$, expressed as the coefficient of variation $(\mathrm{CV}, 100 \times \mathrm{SD} / \mathrm{mean})$, was highest $(29 \%)$ for stations along the TOPEX transect and lowest $(11 \%)$ in the South area.

\section{Relationship between $b_{\mathrm{bp}}$ and particles}

The variation in $b_{\mathrm{bp}}(532)$ as a function of chl $a$ is examined in Fig. 5a $(\mathrm{N}=49, z<100 \mathrm{~m})$. The mean specific backscattering coefficient with respect to chl a $\left(b^{*}{ }_{\text {bp,chl } a}(532)\right)$ was $0.005 \mathrm{~m}^{2}(\mathrm{mg} \mathrm{chl} a)^{-1}$, with $\mathrm{SD}$ of $0.003 \mathrm{~m}^{2}(\mathrm{mg} \mathrm{chl} a)^{-1}$. For the upper $40 \mathrm{~m}(\mathrm{~N}=$ $29), b^{*}{ }_{\text {bp,chl a }}(532)$ had a mean value of $0.0042 \pm 0.0014$ $\mathrm{m}^{2}(\mathrm{mg} \mathrm{chl} \mathrm{a})^{-1}$. South and North of the front we found similar $b^{*}{ }_{\text {bp,chl a }}(532)$ values (South, $0.0050 \pm$ 0.0007 , and North, $\left.0.0050 \pm 0.0009 \mathrm{~m}^{2}(\mathrm{mg} \mathrm{chl} \mathrm{a})^{-1}\right)$, whereas along the TOPEX transect (i.e. across the front), $b^{*}{ }_{\text {bp, chl a }}$ (532) was significantly lower (0.0024 \pm $0.0006 \mathrm{~m}^{2}(\mathrm{mg} \mathrm{chl} \mathrm{a})^{-1}$; ANOVA for the 3 areas, $z<40 \mathrm{~m}, \mathrm{~N}=29, F=38.0, \mathrm{p}<0.0001)$. To verify the cause of these differences in $b^{*}{ }_{\mathrm{bp}, \mathrm{chl}}$ a within the study area, we used empirical relationships and constructed a budget for $b_{\mathrm{bp}}$.

Empirical relationships between the backscattering coefficient and different types of particles are presented in Fig. 5b-d and Fig. 6. It may be hypothesized that the presence of small detrital particles (including minerals), may increase $b_{\mathrm{bp}}$ in the South or North areas relative to the TOPEX (frontal) area. However, this hypothesis is not supported by our 

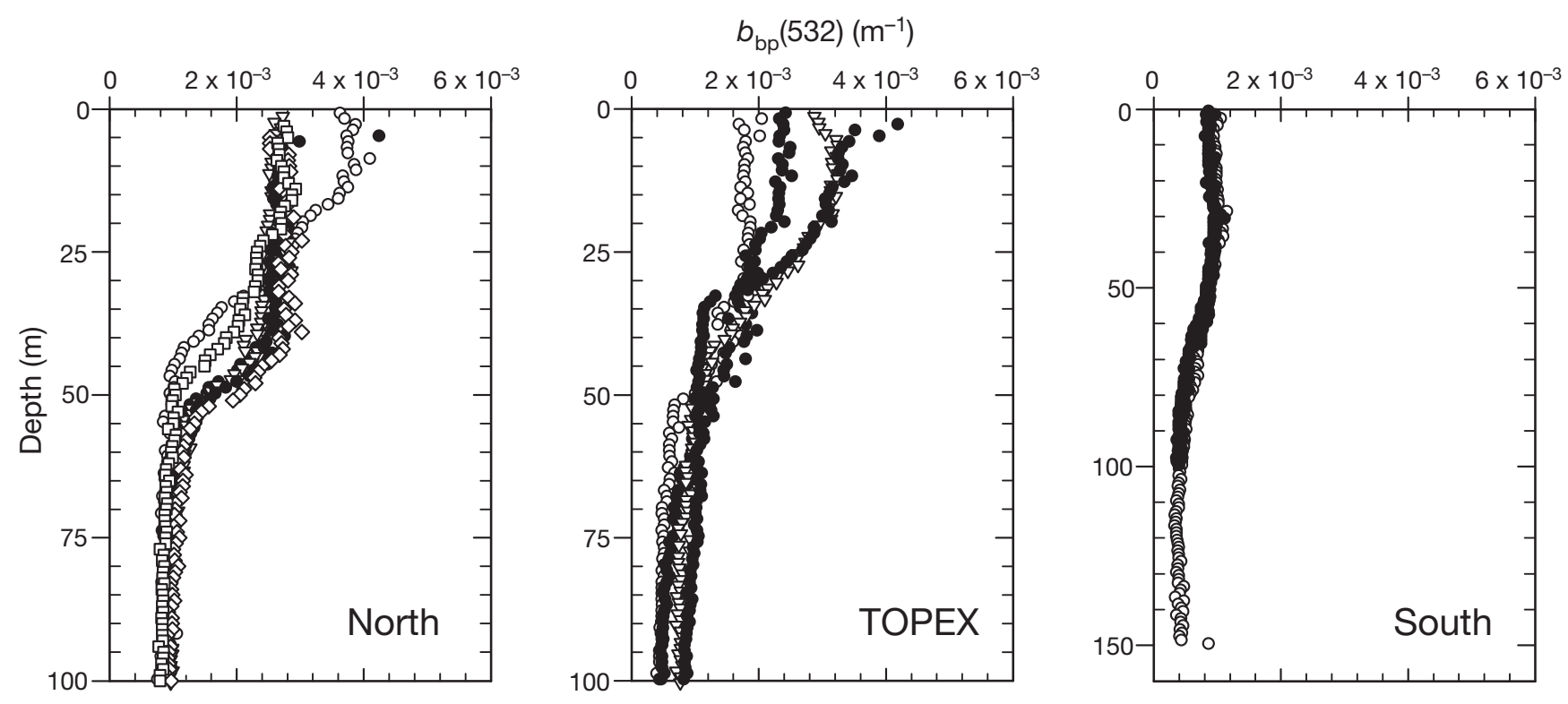

Fig. 4. Variability in backscattering coefficient with depth in different casts in 3 areas
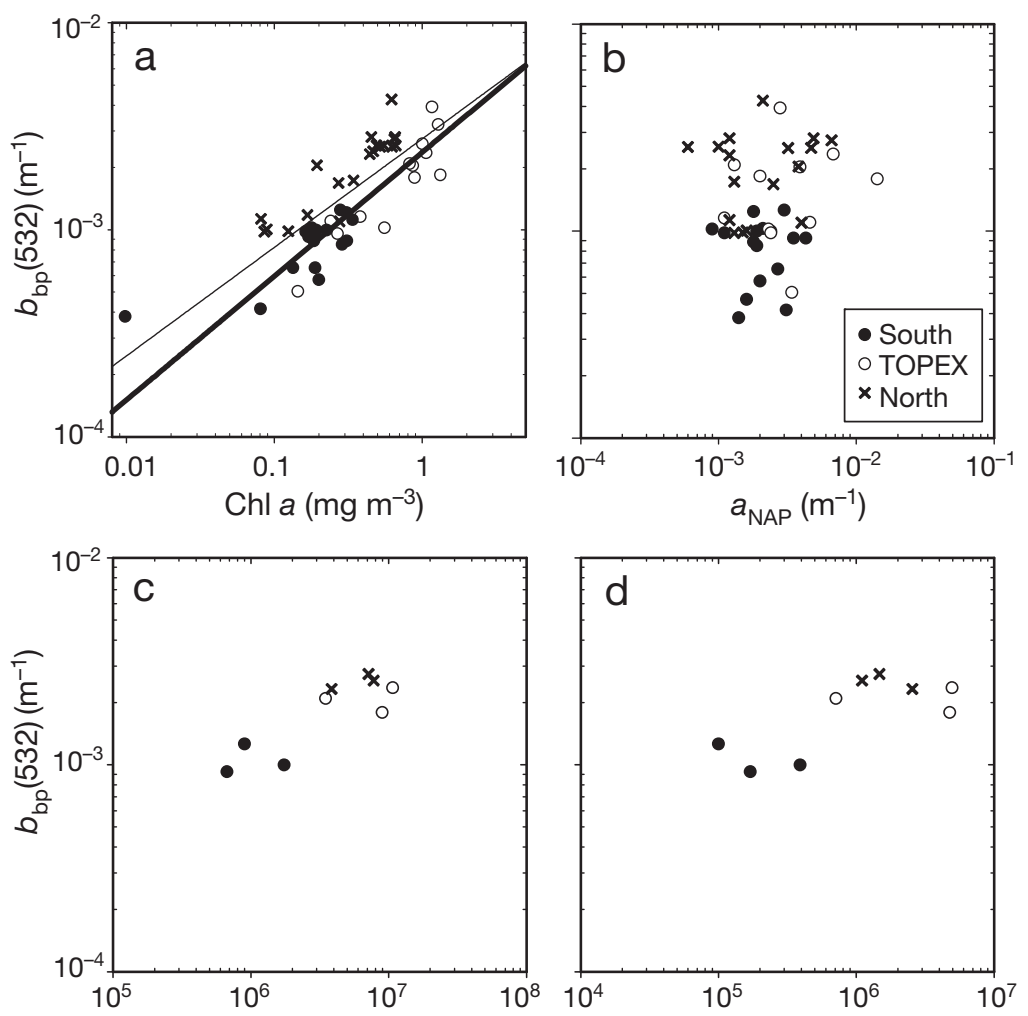

Dinoflagellates $(d>20 \mu \mathrm{m})\left(\right.$ cells $\left.\mathrm{m}^{-3}\right)$ Diatoms $(d>20 \mu \mathrm{m})\left(\right.$ cells $\left.\mathrm{m}^{-3}\right)$

Fig. 5. $b_{\text {bp }}(532)$ as a function of (a) chl $a$, where the thin line is the power law fit on all data from ECOMAR cruise $(z<100 \mathrm{~m})$ : $b_{\mathrm{bp}}(532)=0.003 \times$ $\operatorname{chl} a^{0.51}, \mathrm{r}^{2}=0.64, \mathrm{~N}=49$, RMSE $=0.26\left(\mathrm{~m}^{-1}\right)$ and Mean Absolute Percent Error $(\mathrm{MAPE})=4.6 \%$. Thick line is regression computed using model of Huot et al. (2008) in their Table 1. Calculation of $\mathrm{r}^{2}$, RMSE and MAPE has been done on $\log _{10}$-transformed data and equations in Huot et al. (2008); (b) absorption coefficient of non-algal particles (a $\mathrm{a}_{\mathrm{NAP}}$ ) at $440 \mathrm{~nm}$;

(c) dinoflagellate abundance; and (d) diatom abundance observation of the variations in $b_{\mathrm{bp}}(532)$ in relation to $a_{\mathrm{NAP}}$ (Fig. $5 \mathrm{~b}, \mathrm{~N}=53, z<100 \mathrm{~m}$ ). Microphytoplankton $(d>20 \mu \mathrm{m})$, in particular dinoflagellate, abundances correlated well with $b_{\mathrm{bp}}\left(\mathrm{r}^{2}=0.5, \mathrm{~N}=9, \mathrm{p}<0.05\right.$, Fig. 5c,d). A linear model with nanoeukaryote abundances (Fig. 6a) explained the highest percentage of variation in $b_{\text {bp }}(532)$, with:

$b_{\mathrm{bpp}}(532)=794 \times 10^{-12}+0.64 \times 10^{-12} C_{\mathrm{p} i}$,

where $i$ is nanoeukaryotes, $\mathrm{r}^{2}=0.68, \mathrm{~N}=$ 50, $F=104, \mathrm{p}<0.0001$. Adding the abundance of cryptophytes to this regression increased the explained variance to $70 \%$ for all data (Table 2). It is worth noting that the relationship between in situ $b_{\mathrm{bp}}$ and in situ bacterial abundance over the whole dataset was very weak $\left(\mathrm{r}^{2}=0.1, \mathrm{~N}=44, \mathrm{p}=\right.$ $0.02)$. For the same points, the relationship in Eq. (4) gives $r^{2}=0.66(\mathrm{~N}=44, \mathrm{p}<0.0001)$.

The capacity of various components of the particle assemblage to predict $b_{\mathrm{bp}}$ in each area was then tested. Table 2 shows the regression statistics only for the most significant relationships in each area. In the South, bacterial abundance alone served to explain $91 \%$ of the variability in $b_{\mathrm{bp}}(532)$. By contrast, along the TOPEX transect, picoeukaryotes alone served to explain $61 \%$ of the variation in $b_{\mathrm{bp}}$ (Table 2), and nanoeukaryotes alone ex- 

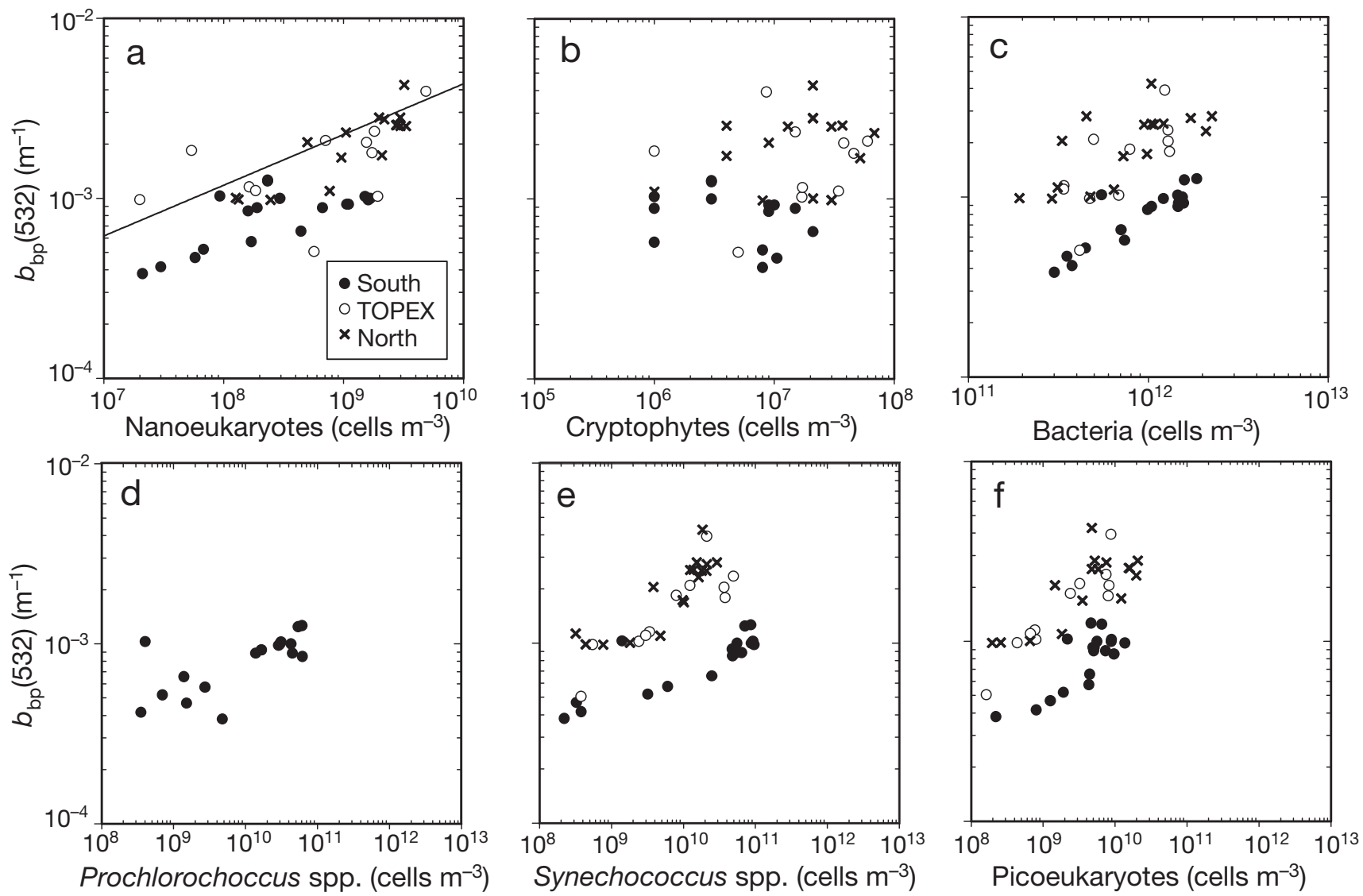

Fig. 6. $b_{\mathrm{bp}}(532)$ as function of abundance of (a) nanoeukaryotes, (b) cryptophytes, (c) bacteria, (d) Prochlorochoccus spp., (e) Synechococcus spp. and (f) picoeukaryotes. Solid line in (a) is linear fit to all data (Eq. 4 in text). Symbols represent different casts

plained $60 \%$ (not shown in Table 2). In the North, nanoeukaryote abundance was the best descriptor of variations in $b_{\mathrm{bp}}$. These shifts in correlation between $b_{\mathrm{bp}}$ and plankton types for the different areas illus-

Table 2. Linear regression results at $532 \mathrm{~nm}$ (mean $\pm \mathrm{SE}$ ) for plankton components (see text) to $100 \mathrm{~m}$ depth. Coefficient units are $\mathrm{m}^{2}$ particle $\mathrm{e}^{-1}$, intercept units are $\mathrm{m}^{-1}$; both must be multiplied by $10^{-12}$. Regression statistics are summarized by coefficients of determination $\left(\mathrm{r}^{2}\right)$ and $F$-ratio. NS: not significant $(\mathrm{p}>0.05) ;{ }^{*} 0.001<\mathrm{p}<0.05{ }^{*}{ }^{* *} \mathrm{p}<0.001$. Example of how table should be read: for the South, $b_{\mathrm{bp}}(532)=300 \times$ $10^{-12}+0.0005 \times 10^{-12} \times C_{\mathrm{pBACT}}, \mathrm{r}^{2}=0.91, \mathrm{~N}=19$

\begin{tabular}{|llcllll}
\hline Area & & $\begin{array}{c}\text { Coefficient } \pm \text { SE } \\
\left(\times 10^{-12}\right)\end{array}$ & $\mathrm{r}^{2}$ & $F$ & $\mathrm{~N}$ \\
& & & & \\
\hline All data & Intercept & $662 \pm 110^{* *}$ & 0.71 & $62^{* *}$ & 50 \\
& Nanoeukaryotes & $0.62 \pm 0.1^{* *}$ & & & \\
& Cryptophytes & $11.1 \pm 4.3^{*}$ & & & \\
South & Intercept & $300 \pm 41.8^{* *}$ & 0.91 & $178^{* *}$ & 19 \\
& Bacteria & $0.0005 \pm 0.0^{* *}$ & & & \\
TOPEX & Intercept & $932 \pm 258^{* *}$ & 0.61 & $17^{*}$ & 11 \\
& Picoeukaryotes & $0.21 \pm 0.1^{* *}$ & & & \\
North & Intercept & $1098 \pm 186^{* *}$ & 0.69 & $43^{* *}$ & 20 \\
& Nanoeukaryotes & $0.60 \pm 0.1^{* *}$ & & & \\
\hline
\end{tabular}

trate how subtle changes in the composition of the plankton community can influence the backscattering signal (Fig. 6).

The slopes of the regressions in Table 2 should not be interpreted strictly as estimates of backscattering cross-section $\left(\sigma_{\mathrm{bbp} i}\right)$ because some of the plankton groups were highly correlated with each other. The $\sigma_{\mathrm{bbpi}}$ derived in this way may therefore overestimate the contribution of each phytoplankton component to $b_{\mathrm{bp}}$. Regardless of the inefficiency of this approach in deriving realistic $\sigma_{\mathrm{bbp} i}$ for living organisms, the relationship of $b_{\mathrm{bp}}$ with living organisms in this study is stronger than with the proxy for biogenic detritus (i.e. $\left.a_{\mathrm{NAP}}\right)$.

\section{Budget for $b_{\mathrm{bp}}$}

To further explore the role of different types of living particles in determining the variability of $b_{\mathrm{bp}}$ we computed $b_{\mathrm{bp}}$ by combining in situ data on cell counts $\left(C_{\mathrm{p} i}\right)$ with culture-based measurements of size $\left(d_{i}\right)$ and backscattering efficiency factors $\left(Q_{\mathrm{bbp} i}\right)$ for 
Table 3. Mean cell diameters (either \pm SD or ranges, in $\mu \mathrm{m}$ ) from literature used in computation of $S_{i}$ to obtain $\sigma_{\mathrm{bbp}}$. Values in italics were used for reference calculation. Additional values illustrate range of observations or laboratory cultures

\begin{tabular}{|c|c|c|c|}
\hline Group & Diameter & Area of sampling & Source \\
\hline Total bacteria & $\begin{array}{c}0.5 \\
0.46 \pm 0.14 \\
0.5 \\
0.56 \\
0.50-0.65 \\
0.39-0.58 \\
0.34-0.75 \\
0.45-0.46 \\
0.55\end{array}$ & $\begin{array}{l}\text { Culture } \\
\text { Subtropical Atlantic } \\
\text { Pacific } \\
\text { Pacific } \\
\text { Western North Atlantic } \\
\text { Bermuda Atlantic } \\
\text { Various locations } \\
\text { Coastal Atlantic } \\
\text { Culture }\end{array}$ & $\begin{array}{l}\text { Vaillancourt et al. (2004) } \\
\text { Zubkov et al. (2000) } \\
\text { Grob et al. (2007) } \\
\text { Chung et al. (1998) } \\
\text { Ulloa et al. (1992) } \\
\text { Gundersen et al. (2002) } \\
\text { Montes-Hugo et al. (2009) } \\
\text { Green et al. (2003) } \\
\text { Stramski et al. (2001) }\end{array}$ \\
\hline Prochlorococcus spp. & $\begin{array}{c}0.71 \\
0.59 \\
0.54 \\
0.68 \pm 0.08 \\
0.63 \pm 0.20 \\
0.74 \\
0.7\end{array}$ & $\begin{array}{l}\text { SARG strain, culture } \\
\text { MED strain, culture } \\
\text { Atlantic } \\
\text { Pacific } \\
\text { Subtropical Atlantic } \\
\text { Pacific } \\
\text { Pacific }\end{array}$ & $\begin{array}{l}\text { Morel et al. (1993) } \\
\text { Morel et al. (1993) } \\
\text { Heywood et al. (2006) } \\
\text { Grob et al. (2007) } \\
\text { Zubkov et al. (2000) } \\
\text { Chung et al. (1998) } \\
\text { Claustre et al. (1999) }\end{array}$ \\
\hline Synechococcus spp. & $\begin{array}{c}1.05 \\
2.5 \\
0.93 \\
0.86 \pm 0.10 \\
1.16 \pm 0.02 \\
0.95 \pm 0.31 \\
0.9 \\
1.2 \\
1.09-1.38 \\
0.92-1.43\end{array}$ & $\begin{array}{l}\text { ROS strain, culture } \\
\text { Culture } \\
\text { Atlantic } \\
\text { Pacific open ocean } \\
\text { Pacific coastal station } \\
\text { Atlantic } \\
\text { Pacific } \\
\text { Pacific } \\
\text { Coastal Atlantic } \\
\text { Culture }\end{array}$ & $\begin{array}{l}\text { Ahn et al. (1992) } \\
\text { Vaillancourt et al. (2004) } \\
\text { Heywood et al. (2006) } \\
\text { Grob et al. (2007) } \\
\text { Grob et al. (2007) } \\
\text { Zubkov et al. (2000) } \\
\text { Chung et al. (1998) } \\
\text { Claustre et al. (1999) } \\
\text { Green et al. (2003) } \\
\text { Morel et al. (1993) }\end{array}$ \\
\hline Picoeukaryotes & $\begin{array}{c}1.4 \\
1.9 \\
1.56 \\
1.37-1.99 \\
2.35 \\
1.26 \\
2.28\end{array}$ & $\begin{array}{l}\text { Micromonas pusilla, culture } \\
\text { Pelagomonas calceolata, culture } \\
\text { Atlantic } \\
\text { Pacific } \\
\text { Atlantic } \\
\text { Pacific } \\
\text { Pacific }\end{array}$ & $\begin{array}{l}\text { Vaillancourt et al. (2004) } \\
\text { Vaillancourt et al. (2004) } \\
\text { Tarran et al. (2006) } \\
\text { Grob et al. (2007) } \\
\text { Zubkov et al. (2000) } \\
\text { Chung et al. (1998) } \\
\text { Claustre et al. (1999) }\end{array}$ \\
\hline Nanoeukaryotes & $\begin{array}{c}6.0 \\
2.0-18.0 \\
3.13 \\
4.3 \\
2.05-2.31 \\
3.97-7.73 \\
11.77\end{array}$ & $\begin{array}{l}\text { Chrysocromulina polylepis, culture } \\
\text { Culture } \\
\text { Atlantic oligotrophic } \\
\text { Atlantic temperate } \\
\text { Coastal Atlantic } \\
\text { Small nanoplankton, culture } \\
\text { Hymenomonas elongata, culture }\end{array}$ & $\begin{array}{l}\text { Vaillancourt et al. (2004) } \\
\text { Vaillancourt et al. (2004) } \\
\text { Tarran et al. (2006) } \\
\text { Tarran et al. (2006) } \\
\text { Green et al. (2003) } \\
\text { Stramski et al. (2001) } \\
\text { Ahn et al. (1992) }\end{array}$ \\
\hline Cryptophytes & $\begin{array}{c}5.4 \\
5.9 \\
5.57 \\
3.0-7.0\end{array}$ & $\begin{array}{l}\text { Guillardia theta } \\
\text { Atlantic } \\
\text { Chroomonas fragarioides, culture } \\
\text { Culture }\end{array}$ & $\begin{array}{l}\text { Vaillancourt et al. (2004) } \\
\text { Tarran et al. (2006) } \\
\text { Ahn et al. (1992) } \\
\text { Vaillancourt et al. (2004) }\end{array}$ \\
\hline Dinoflagellates & $\begin{array}{c}31 \\
27.64\end{array}$ & $\begin{array}{l}\text { Alexandrium tamarensis } \\
\text { Prorocentrum micans }\end{array}$ & $\begin{array}{l}\text { Vaillancourt et al. (2004) } \\
\text { Ahn et al. (1992) }\end{array}$ \\
\hline Diatoms & $\begin{array}{c}18 \\
11.77\end{array}$ & $\begin{array}{l}\text { Thalassiosira rotula } \\
\text { Hymenomonas elongata }\end{array}$ & $\begin{array}{l}\text { Vaillancourt et al. (2004) } \\
\text { Ahn et al. (1992) }\end{array}$ \\
\hline
\end{tabular}

each particle type (i) taken from the literature. We then examined whether in situ measurements of $b_{\mathrm{bp}}$ were reproducible from the measured bacterial and phytoplankton abundances. The $b_{\mathrm{bp}}$ values were computed using Eq. (3) for each particle type, and then all contributions were added as in Eq. (2). We stress that $C_{\mathrm{p} i}$ is the only in situ measurement used, that $d_{i}$ and $Q_{\mathrm{bbp} i}$ come from the literature and that the $b_{\mathrm{bp}}$ computed was verified against in situ $b_{\mathrm{bp}}$.

First, a reference $b_{\mathrm{bp}}$ was computed using $d_{i}$ and $Q_{\mathrm{bbpi}}$ (Tables $3 \& 4$ ) for the 4 groups of organisms considered: bacteria, pico-, nano- and microphytoplank- 
Table 4 . Backscattering efficiency factors $\left(Q_{\mathrm{bbpi}}\right.$ dimensionless) from the literature used in the computation of $\sigma_{\mathrm{bbpi}}$. Values in italics have been used for reference calculation. Additional values illustrate range of observations or laboratory cultures

\begin{tabular}{|c|c|c|c|c|}
\hline Group & $\mathrm{Q}_{\mathrm{bbpi}}$ & $\begin{array}{l}\text { Wavelength } \\
\text { of } Q_{\mathrm{bbp}}(\mathrm{nm})\end{array}$ & Species & Source \\
\hline \multirow[t]{3}{*}{ Total bacteria } & 0.0039 & 510 & Undefined species, culture & Vaillancourt et al. (2004) \\
\hline & $0.005-0.0090$ & 530 & $\begin{array}{l}\text { Strain from Villefranche-sur-Mer } \\
\text { coast, culture }\end{array}$ & Morel \& Ahn (1990) \\
\hline & $0.0023-0.0026$ & 488 & Coastal Atlantic & Green et al. (2003) \\
\hline \multirow[t]{2}{*}{ Prochlorococcus spp. } & 0.0008 & 500 & SARG strain, culture & Morel et al. (1993) \\
\hline & 0.0011 & 500 & MED strain, culture & Morel et al. (1993) \\
\hline \multirow[t]{5}{*}{ Synechococcus spp. } & 0.0007 & 550 & ROS strain, culture & Ahn et al. (1992) \\
\hline & 0.0024 & 510 & Synechococcus elongatus, culture & Vaillancourt et al. (2004) \\
\hline & 0.0006 & 500 & MAX01-Low light, culture & Morel et al. (1993) \\
\hline & 0.0004 & 500 & ROS and MAX, culture & Morel et al. (1993) \\
\hline & $0.0013-0.0022$ & 488 & Coastal Atlantic & Green et al. (2003) \\
\hline \multirow[t]{2}{*}{ Picoeukaryotes } & 0.0065 & 510 & Micromonas pusilla, culture & Vaillancourt et al. (2004) \\
\hline & 0.003 & 510 & Pelagomonas calceolata, culture & Vaillancourt et al. (2004) \\
\hline \multirow[t]{5}{*}{ Nanoeukaryotes } & 0.019 & 510 & Chrysocromulina polylepis, culture & Vaillancourt et al. (2004) \\
\hline & $0.0018-0.0643$ & 510 & Culture & Vaillancourt et al. (2004) \\
\hline & 0.0015 & 550 & Hymenomonas elongata, culture & Ahn et al. (1992) \\
\hline & $0.0013-0.0019$ & 550 & Other nanoplankton, culture & Ahn et al. (1992) \\
\hline & $0.0013-0.0020$ & 488 & Coastal Atlantic & Green et al. (2003) \\
\hline \multirow[t]{3}{*}{ Cryptophytes } & 0.0029 & 510 & Guillardia theta, culture & Vaillancourt et al. (2004) \\
\hline & $0.0095-0.0258$ & 510 & Culture & Vaillancourt et al. (2004) \\
\hline & 0.0015 & 550 & Chroomonas fragarioides, culture & Ahn et al. (1992) \\
\hline \multirow[t]{2}{*}{ Dinoflagellates } & 0.0148 & 510 & Alexandrium tamarensis, culture & Vaillancourt et al. (2004) \\
\hline & 0.00458 & 550 & Prorocentrum micans, culture & Ahn et al. (1992) \\
\hline \multirow[t]{2}{*}{ Diatoms } & 0.0054 & 510 & Thalassiosira rotula, culture & Vaillancourt et al. (2004) \\
\hline & 0.00149 & 550 & Hymenomonas elongata, culture & Ahn et al. (1992) \\
\hline
\end{tabular}

ton. For pico- and nanophytoplankton, $d_{i}$ and $Q_{\mathrm{bbp} i}$ values were taken from a recent study (Vaillancourt et al. 2004), except for Synechococcus spp. values, which were derived from measurements of a freshwater species (S. elongatus), and for Prochlorococcus spp. values, which were not measured by Vaillancourt et al. (2004). In those cases we used values from Ahn et al. (1992) and Morel et al. (1993) respectively. Mean microscopy counts for diatoms and dinoflagellates were used for microphytoplankton for each area. Note that there is a mismatch between the size of the diatoms counted $(d>20 \mu \mathrm{m})$ and the size of diatom species on which the values in Table 3 are based, which were smaller. We then evaluated the capacity of the reference calculation of $b_{\mathrm{bp}}$ (x-axis, Fig. 7) to explain the variations of in situ $b_{\mathrm{bp}}$ data (yaxis, Fig. 7). Because of the need to have coincident counts and $b_{\mathrm{bp}}$, the dataset was reduced to $\mathrm{N}=44$ $(z \leq 100 \mathrm{~m})$. The reference $b_{\mathrm{bp}}$ suffices to explain $55 \%$ of the variation of the in situ data, with a linear regression of slope $0.7 \mathrm{~m}^{2}$ particle ${ }^{-1}$, and intercept at $5 \times 10^{-4} \mathrm{~m}^{-1}(\mathrm{p}<0.01)$. We also used 2 indicators of

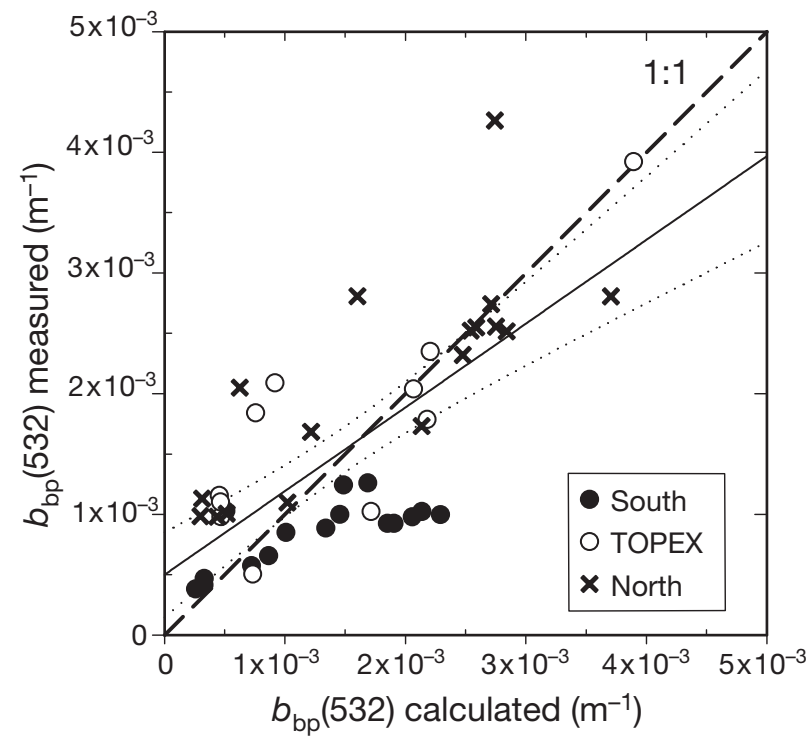

Fig. 7. Variation in measured $b_{\mathrm{bp}}(532)$ explained by reference-calculated $b_{\mathrm{bp}}$. Solid line: linear regression fit to data from 3 areas combined: $b_{\mathrm{bp}}(532)_{\text {modelled }}=0.0005+0.7 \times$ $b_{\text {bp }}(532)_{\text {measured, }} \mathrm{r}^{2}=0.54, \mathrm{~N}=44, \mathrm{p}<0.005(z<100 \mathrm{~m})$; dotted lines: $95 \% \mathrm{CI}$; dashed line: one-to-one line 


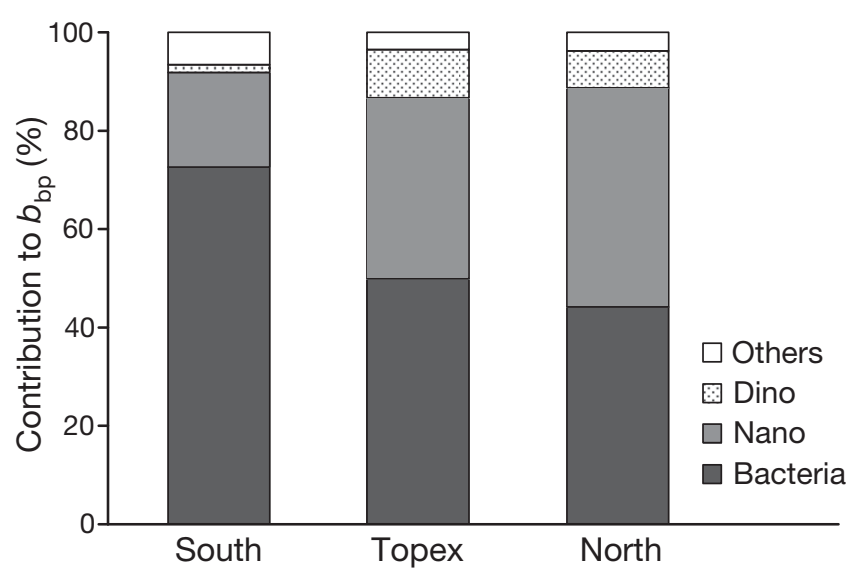

Fig. 8. Average percent contribution of 4 particle classes to $b_{\mathrm{bp}}$ calculated from reference $b_{\mathrm{bp}}$ in the 3 areas

accuracy and precision of fit, based on the residual (i.e. the difference between $b_{\mathrm{bp}}$ calculated and $b_{\mathrm{bp}}$ in situ): the median and the mean of the percentile range (i.e. 84th-16th percentile/2). For the reference calculation the median of the residual was $-0.8 \%$ and the mean of the percentile range was $77.7 \%$.

Despite not being able to reproduce all the variability observed in $b_{\mathrm{bp}}$, we use here the reference $b_{\mathrm{bp}}$ calculated to interpret the contribution of each organism to $b_{\mathrm{bp}}$. This contribution was computed as the percentage of the contribution to $b_{\mathrm{bp}}$ by each particle type (i.e. $\left.b_{\mathrm{bpi}} / b_{\mathrm{bp}} \times 100\right)$ for each of the 44 points used. We report the average percentages calculated for all data taken together and separated by area (Fig. 8).

For all data, bacteria were the most important contributors to $b_{\mathrm{bp}}$ (with an average of $56 \%$ ), followed by nanoeukaryotes $(33 \%)$ and dinoflagellates (6\%). These contributions varied by area: in the South, where conditions were more oligotrophic, bacteria dominated the $b_{\mathrm{bp}}$. In the North, at intermediate chl $a$ concentrations out of the front, nanoeukaryotes were the most important, and along the TOPEX transect, across the very productive front, dinoflagellates appeared to have a greater role.

In these calculations, the only value that changed between areas was the abundance of each plankton type $\left(C_{\mathrm{p} i}\right)$, which was measured in situ; $Q_{\mathrm{bbpi}}$ and $d_{i}$ were kept constant for all areas. This highlights the fact that the estimated changes in the contribution to $b_{\mathrm{bp}}$ were determined solely by changes in abundances of each component. As mentioned in 'Pigments and counts', above, bacterial abundances were not significantly different from area to area, but the abundances of nanoeukaryotes and dinoflagellates changed in the TOPEX and North areas relative to the South. According to this budget, the changes in nanoeukaryote and dinoflagellate abundance were responsible for the observed changes in $b_{\mathrm{bp}}$, with bacteria providing a high, almost constant background contribution to the particle backscattering coefficient.

\section{Sensitivity analysis}

In order to support our choice of reference $Q_{\mathrm{bbp}}$ and $d_{i}$ values, we performed a sensitivity analyis. Maximum $Q_{\mathrm{bbpi}}$ and $d_{i}$ values (from Tables $3 \& 4$ ) were combined for each organism type to produce the maximum backscattering cross-section, $\sigma_{\mathrm{bbp}}$, for each type of organism. Minimum $Q_{\mathrm{bbpi}}$ and $d_{i}$ were used similarly to produce the minimum $\sigma_{\mathrm{bbp} i}$. The backscattering cross-section was varied within this range for each type of organism in turn, leaving the rest with the $\sigma_{\mathrm{bbp} i}$ used in the reference calculation. The abundances $\left(C_{\mathrm{pi}}\right)$ were left unchanged (i.e. the measured values were used for each of the 44 points) as in the reference $b_{\mathrm{bp}}$ (Fig. 9), and $\sigma_{\mathrm{bbp} i}$ and $C_{\mathrm{p} i}$ were then used to compute $b_{\mathrm{bp}}$. The effect of the change in $\sigma_{\mathrm{bbp} i}$ was assessed using statistics of the fit between in situ and modelled $b_{\mathrm{bp}}$ : slope, intercept, $\mathrm{r}^{2}$, median percentage difference and mean of percentile range, with results presented in Fig. 9. For comparison, the statistics of the reference $b_{\mathrm{bp}}$ are shown in Fig. 9. The first conclusion is that the values chosen for the reference $b_{\mathrm{bp}}$ minimize the error statistics on the fit with in situ $b_{\mathrm{bp}}$.

However, the most salient feature is the large effect of $\sigma_{\mathrm{bbp} i}$ for nanoeukaryotes and bacteria. This is due to their important contribution to $b_{\mathrm{bp}}$ (Fig. 8), which in turn, is related to their $C_{\mathrm{p} i}$ (Table 1). Dinoflagellates and diatoms have $C_{\mathrm{p} i}$ similar to nanoeukaryotes, yet their impact in the statistics of the sensitivity analysis is reduced. This is likely due to the use of average values of $C_{\mathrm{p} i}$ for each region.

\section{Effect of $Q_{\mathrm{bbp}}$ on $b_{\mathrm{bp}}$}

Given the high impact of nanoeukaryotes and bacteria on $b_{\mathrm{bp}}$ in our dataset, we attempted to simplify our model of the backscattering coefficient by considering only those 2 components and change the $Q_{\mathrm{bbp}}$ simultaneously, based on 2 sets of values reported in the literature (Table 4 ). We held $C_{\mathrm{p} i}$ and $d_{i}$ the same for all data $(\mathrm{N}=44, z<100 \mathrm{~m}$, Fig. 10). The effect of choosing one or the other sets of values of $Q_{\mathrm{bbp} i}$ is highlighted by adding components to $b_{\mathrm{bp}}$ sequentially, 

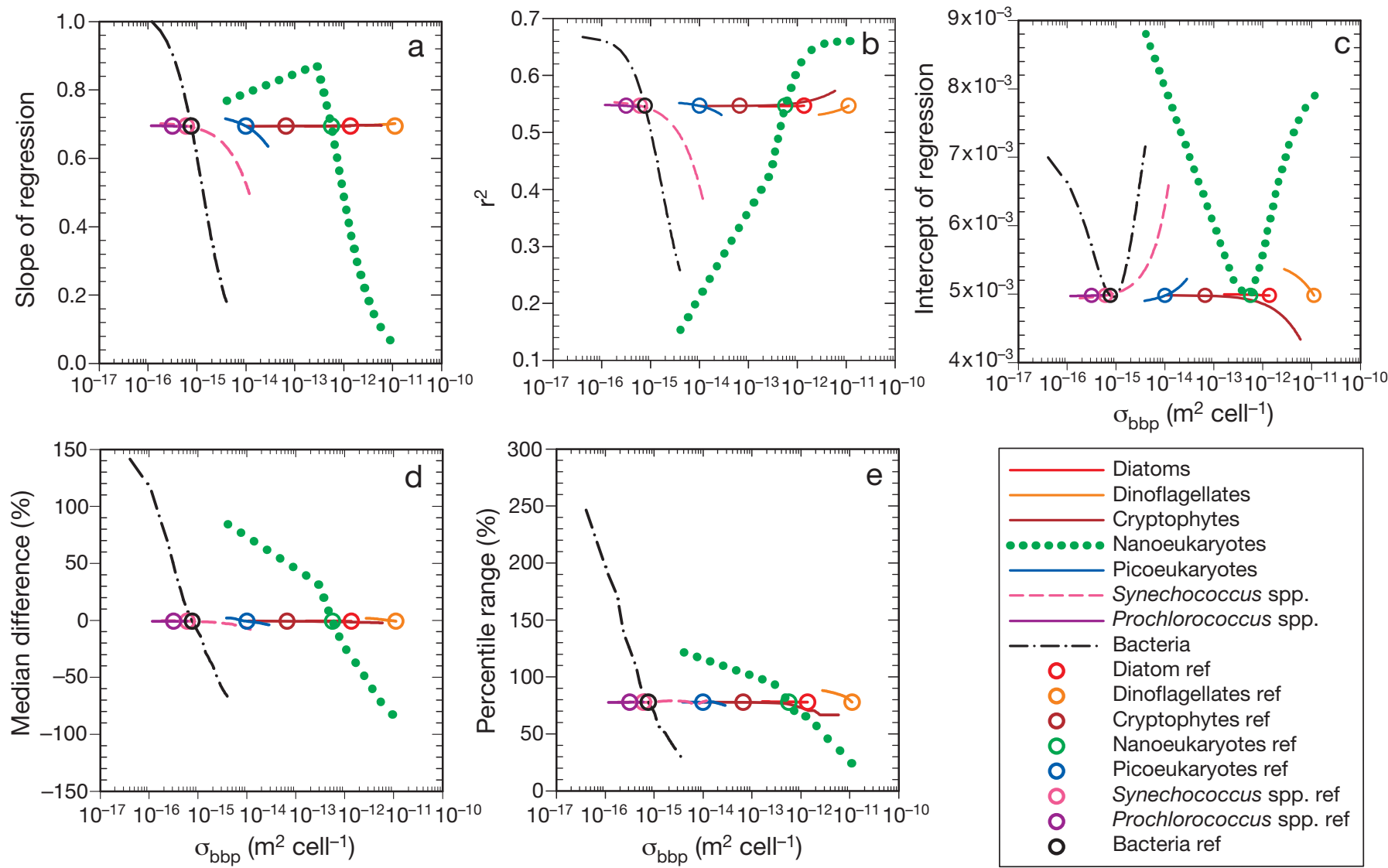

Fig. 9. Effect of changing $\sigma_{\mathrm{bbpi}}$ for different types of plankton on statistics of fit between in situ and modelled $b_{\mathrm{bp}}$. (a) Slope of regression; (b) $\mathrm{r}^{2}$ of regression; $(\mathrm{c})$ intercept of regression; $(\mathrm{d})$ median absolute difference between in situ and modelled $b_{\mathrm{bp}}(\mathrm{a}$ measure of accuracy); (e) mean percentile range (a measure of precision; see text). Ref = values from reference calculation

first using only nanoeukaryotes or bacteria, then using both of these and regressing them against measured $b_{\mathrm{bp}}$ (Fig. 10). Using only nanoeukaryotes, we obtained a slope of 15 for lower $Q_{\mathrm{bbpi}}$ (Fig. 10a) and a slope of 1.1 for higher $Q_{\mathrm{bbpi}}$ (Fig. 10b). Bacteria on their own did not serve to explain much of the variability in $b_{\text {bp }}$ for either maximum or minimum values of $Q_{\mathrm{bbp} i}$ (Figs 10c,d). Using $Q_{\mathrm{bbpi}}$ low for bacteria in combination with $Q_{\mathrm{bbpi}}$ high for nanoeukaryotes yielded the best explanation of in situ $b_{\mathrm{bp}}$ (Fig. 10e,f).

The latter result was similar to the reference simulation (Fig. 7), indicating that it is possible to reproduce a large fraction of the observed variability in our $b_{\mathrm{bp}}$ data by considering nanoeukaryotes and bacteria only.

\section{DISCUSSION}

This study, which complements previous studies in neighbouring regions ( $\mathrm{Li}$ et al. 1992, Li \& Harrison 2001, Li 2002), is the first to characterise pico- and nanophytoplankton communities in the area of the MAR around the Charlie Gibbs Fracture Zone. At this location, in the summer, we found a thermal front with enhanced biological activity, which enabled us to distinguish 2 different biological communities with bio-optical effects on $a_{\mathrm{NAP}}$ and $b_{\mathrm{bp}}$. The ratio $a_{\mathrm{NAP}}: a_{\mathrm{p}}$ decreased with increasing chl a levels (Fig. 3), following a similar trend to what has been found in the Sargasso Sea and Peruvian upwelling for biogenically produced detritus (see e.g. Fig. 18 in Bricaud \& Stramski 1990). This concurs with the low estimates (5 to $\left.10 \mathrm{~g} \mathrm{~m}^{-2} \mathrm{yr}^{-1}\right)$, from satellite imagery and sediment traps, of aeolian mineral deposition in the area (Mahowald et al. 2005, Maher et al. 2010). These provide indirect evidence of a principally biogenic detritus contribution to the particulate detritus in the area.

We found that the relationship between $b_{\mathrm{bp}}$ and chl $a$ agreed with relationships found in other studies that use larger datasets (Huot et al. 2008, Fig. 6a) and that the coefficients ( $\alpha$ and $\beta$ ) of a power-law fit (i.e. $b_{\mathrm{bp}}=\alpha[\mathrm{chl} a]^{\beta}$ ) were comparable. At $532 \mathrm{~nm}$, our study yielded $\alpha=0.003$ and $\beta=0.5$, whereas Huot et 

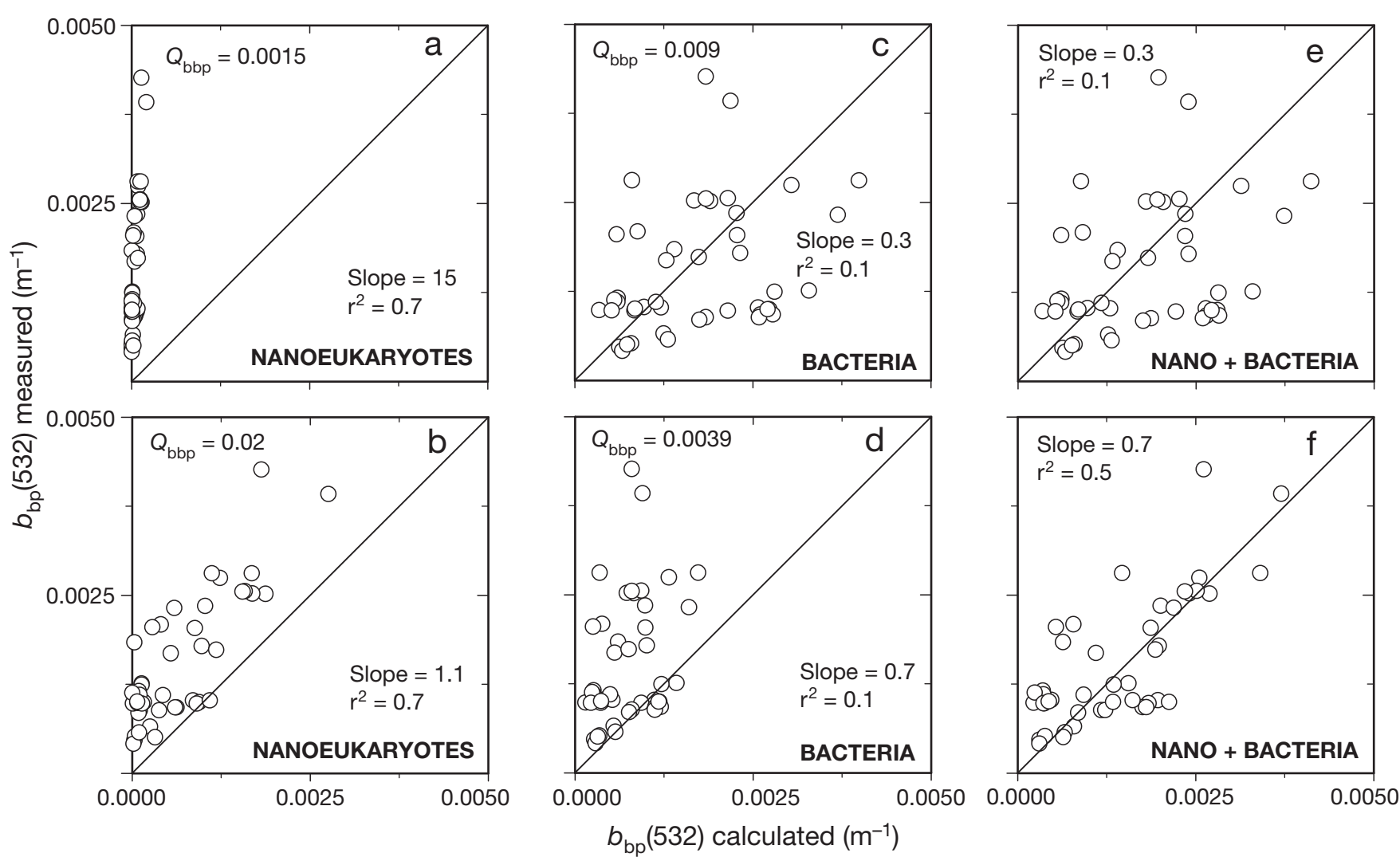

Fig. 10. Comparison between $b_{\mathrm{bp}}$ measured and $b_{\mathrm{bp}}$ calculated $(\mathrm{N}=44)$ using different $Q_{\mathrm{bbp} i}$ (dimensionless) values from the literature and including different living components. Diameter value used for all calculations is the value used for reference $b_{\mathrm{bp}}$ from Table 3 (in italics). Solid line: one-to-one line. $Q_{\mathrm{bbp} i}$ values from Stramski et al. (2001) used in (a), (c) and (e), with $Q_{\mathrm{bbp} i}$ in (e) as in (a) and (c). $Q_{\mathrm{bbpi}}$ values from Vaillancourt et al. (2004) used in (b), (d) and (f), with $Q_{\mathrm{bbpi}}$ in (f) as in (b) and (d)

al. (2008) reported $\alpha=0.002$ and $\beta=0.6$. In the north polar Atlantic, Stramska et al. (2003) reported $\alpha=$ 0.0019 and $\beta=0.5$.

Theoretical predictions suggest that bacteria are the principal living contributors to the backscattering coefficient (Stramski et al. 2001), consistent with our findings that bacteria are, on average, responsible for $50 \%$ of the $b_{\mathrm{bp}}$. However, bacteria are not the main cause of the variation in the backscattering coefficient in this area, as indicated by the weak relationship between in situ $b_{\mathrm{bp}}$ and in situ bacterial abundance over the whole dataset $\left(\mathrm{r}^{2}=0.1, \mathrm{~N}=44, \mathrm{p}=\right.$ $0.02)$. Instead, any increase of in situ $b_{\mathrm{bp}}$ was related to an increase in nanoeukaryote abundance, which explained a large fraction (almost 70\%) of the variance in $b_{\mathrm{bp}}$.

Using the $b_{\mathrm{bp}}$ budget, we were able to separate the effects of the abundance and backscattering crosssections of each organism. Whilst bacterial abundance was similar across the study area, and contributed to a large fraction of the total $b_{\mathrm{bp}}$ measured, the variations in calculated $b_{\mathrm{bp}}$ were caused by an increase in nanoeukaryote and dinoflagellate abundance (Fig. 8). Thus, for a given level of chl $a_{\text {, the }}$ increased abundance of a particular phytoplankton type will determine the $b_{\mathrm{bp}}$ associated with it. This could have implications for satellite detection of phytoplankton types. For example, methods have been proposed to relate absorption spectra or chlorophyll concentration to phytoplankton community structure (Brewin et al. 2011, Devred et al. 2011, Hirata et al. 2011). Whitmire et al. (2010) have proposed that field backscattering-to-chlorophyll ratios may be subject to variations of up to $30 \%$ due to the mix of phytoplankton types. Our results suggest that the large variations observed in the relationship between chl $a$ and $b_{\mathrm{bp}}$ (Antoine et al. 2011) may be related to local variations in abundance of a particular phytoplankton group, and hence $b_{\mathrm{bp}}$ determined from satellite imagery could provide additional constraints on existing models of phytoplankton functional types.

We are aware that a number of issues could affect the interpretation of our results. One is the potential 
under-representation of the particle pool, e.g. by ignoring the contribution of bubbles, mis-representing the organogenic detritus fraction by using $a_{\mathrm{NAP}}$ and using a small sample to characterise the abundance of microphytoplankton (Fig. 5c,d). Another problem might be the sensitivity of the results to choice of $\sigma_{\text {bbpi }}$ (Fig. 9).

In addition to the considerations above, the inherent simplicity of the approach used here, where we have assumed mean sizes $\left(d_{i}\right)$ and $Q_{\mathrm{bbpi}}$ for each particle type, may also result in underestimations in the $b_{\mathrm{bp}}$ budget. However, in the absence of data on size variation, it is not possible to quantify any such effects, if present. A possibility for future studies would be to do separate counts on samples filtered through different pore-sizes, to permit better sizing of the organisms. Additionally, using the side-scattering signal from flow cytometry as an approximation of $\sigma_{\mathrm{bbp} i}$ might help with limiting uncertainties in in situ characterisation of $Q_{\mathrm{bbpi}}$ and size. Ideally, particle size distribution changes should be included in the budget construction, in an approach similar to that of Green et al. $(2003 a, b)$.

\section{CONCLUSIONS}

Coincident $b_{\mathrm{bp}}$ and plankton counts were made in a remote area of the central North Atlantic, where a frontal zone provided different habitats for significantly different plankton communities. Bacteria accounted for the greatest contribution to $b_{\mathrm{bp}}$, but the variation in this coefficient was related to changes in phytoplankton abundance (nanoeukaryotes). This result is affected by backscattering efficiency factors and particle size, as well as abundance, as shown through sensitivity analysis. Relatively large back scattering efficiency values for nanoeukaryotes were required to reproduce measured $b_{\mathrm{bp}}$. We found no supporting evidence that the detrital component played a significant role in $b_{\mathrm{bp}}$ at this site, although this is inconclusive, given the limited methods available to test this result. A significant methodological advance is required to better quantify and characterise the organogenic detritus, before the remaining proportion of the variation in $b_{\mathrm{bp}}$ can be explained.

Acknowledgements. This work was funded by the ECOMAR consortium (NERC project no. NE/C512961/1). The authors gratefully acknowledge the loan of equipment from the NERC Field Spectroscopy Facility and the provision of satellite imagery from NEODAAS. We thank the master and the crew of the RRS 'James Cook' for their help during the JC11 cruise. The training on flow cytometry analysis by G. Tarran and on microscopy identification by C. Widdicombe is very much appreciated. We thank B. A. Maher for her advice on dust deposition rates over the North Atlantic. We thank G. Dall'Olmo, T. Platt and G. Mitchelson-Jacobs for their useful discussions, and 3 anonymous reviewers for their comments on the manuscript.

\section{LITERATURE CITED}

Ahn YH, Bricaud A, Morel A (1992) Light backscattering efficiency and related properties of some phytoplankters. Deep-Sea Res A 39:1835-1855

> Antoine D, Siegel DA, Kostadinov T, Maritorena S, and others (2011) Variability in optical particle backscattering in contrasting bio-optical oceanic regimes. Limnol Oceanogr 56:955-973

Barlow R, Cummings DG, Gibb SW (1997) Improved resolution of mono- and divinyl chlorophylls $a$ and $b$ and zeaxanthin and lutein in phytoplankton extracts using reverse phase C-8 HPLC. Mar Ecol Prog Ser 161:303-307

Bernard S, Probyn TA, Quirantes A (2009) Simulating the optical properties of phytoplankton cells using a twolayered spherical geometry. Biogeosciences Discuss 6: 1497-1563

Boss E, Stramski D, Bergman T, Pegau WS, Lewis M (2004) Why should we measure the optical backscattering coefficient? Oceanography 17:44-49

$>$ Brewin RJW, Hardman-Mountford NJ, Lavender SJ, Raitsos DE, and others (2011) An intercomparison of bio-optical techniques for detecting dominant phytoplankton size class from satellite remote sensing. Remote Sens Environ 115:325-339

Bricaud A, Stramski D (1990) Spectral absorption-coefficients of living phytoplankton and nonalgal biogenous matter-a comparison between the Peru upwelling area and the Sargasso sea. Limnol Oceanogr 35:562-582

Chung SP, Gardner WD, Landry MR, Richardson MJ, Walsh ID (1998) Beam attenuation by microorganisms and detrital particles in the equatorial Pacific. J Geophys Res 103:12669-12681

- Claustre H, Morel A, Babin M, Cailliau C, and others (1999) Variability in particle attenuation and chlorophyll fluorescence in the tropical Pacific: scales, patterns, and biogeochemical implications. J Geophys Res 104:3401-3422

> Devred E, Sathyendranath S, Stuart V, Platt T (2011) A three component classification of phytoplankton absorption spectra: application to ocean-color data. Remote Sens Environ 115:2255-2266

> Durand MD, Olson RJ (1996) Contributions of phytoplankton light scattering and cell concentration changes to diel variations in beam attenuation in the equatorial Pacific from flow cytometric measurements of pico-, ultra- and nanoplankton. Deep-Sea Res II 43:891-906

Green RE, Sosik HM, Olson RJ (2003a) Contributions of phytoplankton and other particles to inherent optical properties in New England continental shelf waters. Limnol Oceanogr 48:2377-2391

Green RE, Sosik HM, Olson RJ, DuRand MD (2003b) Flow cytometric determination of size and complex refractive index for marine particles: comparison with independent and bulk estimates. Appl Opt 42:526-541

Grob C, Ulloa O, Claustre H, Huot Y, Alarcon G, Marie D (2007) Contribution of picoplankton to the total particu- 
late organic carbon concentration in the eastern South Pacific. Biogeosciences 4:837-852

Gundersen K, Orcutt KM, Purdie DA, Michaels AF, Knap AH (2001) Particulate organic carbon mass distribution at the Bermuda Atlantic Time-series Study (BATS) site. Deep-Sea Res II 48:1697-1718

- Hirata T, Hardman-Mountford NJ, Brewin RJW, Aiken J, and others (2011) Synoptic relationships between surface chlorophyll-a and diagnostic pigments specific to phytoplankton functional types. Biogeosciences 8:311-327

Huot Y, Morel A, Twardowski MS, Stramski D, Reynolds RA (2008) Particle optical backscattering along a chlorophyll gradient in the upper layer of the eastern South Pacific Ocean. Biogeosciences 5:495-507

Letessier TB, Cox MJ, Brierley AS (2009) Drivers of euphausiid species abundance and numerical abundance in the Atlantic Ocean. Mar Biol 156:2539-2553

Levitus S (1982) Climatological atlas of the world ocean, prof paper no. 13. National Oceanic and Atmospheric Administration, Washington, DC

Li WKW (2002) Macroecological patterns of phytoplankton in the northwestern North Atlantic Ocean. Nature 419: 154-157

Li WKW, Harrison WG (2001) Chlorophyll, bacteria and picophytoplankton ecological provinces of the North Atlantic. Deep-Sea Res II 48:2271-2293

Li WKW, Dickie PM, Irwin BD, Wood AM (1992) Biomass of bacteria, cyanobacteria, prochlorophytes and photosynthetic eukaryotes in the Sargasso Sea. Deep-Sea Res I 39:501-519

Maher BA, Prospero JM, Mackie D, Gaiero D, Hesse PP, Balkanski Y (2010) Global connections between aeolian dust, climate and ocean biogeochemistry at the present day and at the last glacial maximum. Earth Sci Rev 99: 61-97

Mahowald NM, Baker AR, Bergametti G, Brooks N, and others (2005) Atmospheric global dust cycle and iron inputs in the ocean. Global Biogeochem Cycles 19:GB4025

Montes-Hugo MA, Ducklow H, Schofield OM (2009) Contribution by different marine bacterial communities to particulate beam attenuation. Mar Ecol Prog Ser 379:13-22

Morel A, Maritorena S (2001) Bio-optical properties of oceanic waters: a reappraisal. J Geophys Res 106: 7163-7180

Morel A, Ahn YH (1990) Optical-efficiency factors of freeliving marine-bacteria - influence of bacterioplankton upon the optical-properties and particulate organiccarbon in oceanic waters. J Mar Res 48:145-175

Morel A, Ahn YH, Partensky F, Vaulot D, Claustre H (1993) Prochlorococcus and Synechococcus: a comparative study of their optical properties in relation to their size and pigmentation. J Mar Res 51:617-649

Oubelkheir K, Claustre H, Sciandra A, Babin M (2005) Bio-optical and biogeochemical properties of different trophic regimes in oceanic waters. Limnol Oceanogr 50: 1795-1809

Perry MJ, Porter SM (1989) Determination of the cross-

Editorial responsibility: Rodney Forster,

Lowestoft, UK section absorption coefficient of individual phytoplankton cells by analytical flow cytometry. Limnol Oceanogr 34:1727-1738

Read JF, Pollard RT, Miller PI, Dale AC (2010) Circulation and variability of the North Atlantic Current in the vicinity of the Mid-Atlantic Ridge. Deep-Sea Res I 57: 307-318

Stramska M, Stramski D, Hapter R, Kaczmarek S, Ston J (2003) Bio-optical relationships and ocean color algorithms for the north polar region of the Atlantic. J Geophys Res 108:3143

> Stramski D, Kiefer DA (1991) Light scattering by microorganisms in the open ocean. Prog Oceanogr 28:343-383

> Stramski D, Bricaud A, Morel A (2001) Modeling the inherent optical properties of the ocean based on the detailed composition of the planktonic community. Appl Opt 40: 2929-2945

Stramski D, Boss E, Bogucki DJ, Voss KJ (2004) The role of seawater constituents in light backscattering in the ocean. Prog Oceanogr 61:27-56

Sullivan JM, Twardowski MS, Donaghay PL, Freeman SA (2005) Use of optical scattering to discriminate particle types in coastal waters. Appl Opt 44:1667-1680

Tarran GA, Zubkov MV, Sleigh MA, Burkill PH, Yallop M (2001) Microbial comunity structure and standing stocks in the NE Atlantic in June and July of 1996. Deep-Sea Res II 48:963-985

> Tarran GA, Heywood JL, Zubkov MV (2006) Latitudinal changes in the standing stocks of nano- and picoeukaryotic phytoplankton in the Atlantic Ocean. Deep-Sea Res II 53:1516-1529

Tassan S, Ferrari GM (1995) An alternative approach to absorption measurements of aquatic particles retained on filters. Limnol Oceanogr 40:1358-1368

> Twardowski MS, Claustre H, Freeman SA, Stramski M, Huot Y (2007) Optical backscattering properties of the 'clearest' natural waters. Biogeosciences 4:1041-1058

Ulloa O, Sathyendranath S, Platt T, Quinones RA (1992) Lightscattering by marine heterotrophic bacteria. J Geophys Res 97:9619-9629

> Ulloa O, Sathyendranath S, Platt T (1994) Effect of the particle-size distribution on the backscattering ratio in seawater. Appl Opt 33:7070-7077

Vaillancourt RD, Brown CW, Guillard RRL, Balch WM (2004) Light backscattering properties of marine phytoplankton: relationships to cell size, chemical composition and taxonomy. J Plankton Res 26:191-212

> Whitmire AL, Scott Pegau W, Karp-Boss L, Boss E, Cowles TJ (2010) Spectral backscattering properties of marine phytoplankton cultures. Opt Express 18:15073-15093

Zhang X, Lewis M, Johnson B (1998) Influence of bubbles on scattering of light in the ocean. Appl Opt 37: 6525-6536

Zubkov MV, Sleigh MA, Burkill PH, Leakey JG (2000) Picoplankton community structure on the Atlantic Meridional Transect: a comparison between seasons. Prog Oceanogr 45:369-386

Submitted: June 5, 2010; Accepted: September 6, 2011 Proofs received from author(s): January 10, 2012 